American Journal of Economics and Business Administration 1 (1) 27-33, 2009

ISSN 1945-5488

(C) 2009 Science Publications

\title{
The Importance of Capturing and Using Financial Information in Small Business
}

\author{
Dorothy Davis, Paul Dunn and Katherine Boswell \\ The University of Louisiana-Monroe, College of Business, \\ 700 University Avenue Monroe, LA 71209
}

\begin{abstract}
Problem statement: Small businesses have not been realizing the advantages of good record-keeping and management of financial records. The purpose of this study was to determine some key issues relating to the recordkeeping practices of small business to help determine areas that are causing this major subgroup of businesses to underutilize their use of captured financial data through business processes. Approach: A survey was distributed to small business owners in the retail apparel industry which looked at different classes of issues that would impact the management and usefulness of financial data generated within the business. Results: The results showed that half of the respondents eschewed any computerized system, preferring the traditional manual approach to managing their financial data. Another discovery was that the majority of respondents did not use external expertise in financial data collection, organization or analysis. Manual system users also didn't generate reports from the financial data nearly as often as computerized system users. Finally, this study showed that a large portion of the respondents that did use computerized systems for financial data management had not participated in the selection of the software. Conclusion: The results of this study helped spotlight areas of shortfalls of small businesses in the best organization and utilization of financial data, which would support the ongoing concerns of these businesses and strengthen them in an economic climate that had not been friendly towards small businesses for quite some time.
\end{abstract}

Key words: Small business, computerized record keeping, manual record keeping, financial software

\section{INTRODUCTION}

Record-keeping in business started in antiquity. The need to keep records may very well have started when businesses became large enough so that the owner needed help keeping track of financial matters or when employees were hired and needed to be watched. There is evidence that many small businesses may not be keeping records as well as they should and that those who keep records do so only to meet minimal reporting requirements. They do not take advantage of these records for use in decision making, controlling or planning.

Focusing attention on small business accounting practices is essential because small businesses are so vital to the economy. In the United States, according to the 2006 Small Business Economy report to the President, "97.5\% of employer and non-employer firms have fewer than 20 employees. Yet cumulatively, these firms account for half of our nonfarm real gross domestic product and they have generated $60-80 \%$ of the net new jobs over the past decade. Entrepreneurs rightly command enormous respect and their contributions to the US economy are followed by academics and policymakers alike" ${ }^{\text {"[15] }}$.

There has been little or no research done to determine what small business owner/owners do in their day-to-day accounting practices and whether they use technical advances to support accounting procedures. Information provided by such a study would be of immeasurable value to accountants, small business advisors, professors and existing small business owners as well as someone just starting a new business. This study presents the results of a national study of small retail clothing and apparel store owners designed to determine the bookkeeping method, accounting software use, the bookkeeping responsibility allocated to personnel and the use/s made of the financial information provided.

Literature review: The literature review is organized into three sections. First is a discussion of computerized

Corresponding Author: Dorothy Davis, The University of Louisiana-Monroe, College of Business, 700 University Avenue Monroe, LA 71209 Tel: 318.342.1119 Fax: 318.342.1191 
versus manual recordkeeping. The results reported in this study deal with record-keeping uses in the small businesses; therefore the second section deals with the various uses that can and should be made from information collected through record keeping and financial statement preparation, as well as the importance of appropriate record-keeping to the success of the business owner. The third section discusses accounting software options.

Manual versus computerized record keeping tools: A predominant shift in accounting practice over the last two decades is the incorporation of technology in financial data collection, analysis and reporting. Computerized record keeping has eclipsed manual recordkeeping in large businesses. This shift is less prevalent in small businesses. Very little is being discussed in the small business literature about their record keeping tools and their use of information generated from accounting practices.

In 1990, a survey was conducted in the Ohio area to determine the extent of computerized tools being used in small businesses. Of the 101 responses, 76 of the firms had computers, 56 had computers with accounting software, with an additional $23 \%$ planning on purchasing accounting software ${ }^{[2]}$.

A more recent study in Australia examined the level of computerization of accounting records in small businesses and the obstacles that caused some to predominantly rely on manual systems. This study found that of the small businesses that didn't computerize record keeping, a vast majority had less than 6 employees and tended to fall in the trades or services sectors. They also found that most of the noncomputerized small businesses had less than $\$ 1$ million in turnover. The obstacles addressed included lack of computer skills of personnel, satisfied with the current method of accounting, cost and lack of time ${ }^{[1]}$.

Both of these studies show that while small businesses in general are switching to computerized accounting methods, the shift is slow and obstacles exist that might not be so prevalent in larger companies due to their increased resources.

Uses of accounting information: A good record keeping and accounting system can help assure that the firm is doing well, can pay its obligations in an orderly fashion when they come due and provide information to the owners for planning and control and to others who have a need to know the firm's financial standing. Linda Pinson lists a set of common general records needed by the small business owner including cash in bank, revenue and expense journal, invoices and sales receipts, petty cash record, inventory records, fixed assets log, accounts receivable, accounts payable, independent contractor record, payroll records, mileage log, travel and entertainment logs, customer records, business checkbook and filing system. The IRS is interested in documents and/or records clearly showing income. The records expected are gross receipts, purchases, expenses, travel, transportation, entertainment, gift expenses, assets and employment taxes (internal revenue service). The various documents needed to support any information presented on the tax return should be retained. Any records kept should be able to provide "information needed to satisfy tax requirements, examine trends, make decisions and implement changes" $"[16]$.

A more simplistic view is presented by Philip Wolitzer, a professor emeritus at Long Island University, specializing in accounting and taxation. He says, "You have the same accounts-assets, liabilities, capital, income and expenses-whether you're a tiny business or a huge business. All a small business has to do is keep track of its assets, the liabilities it owes, the income coming in and the expenses it's paying out" ${ }^{\text {"[12] }}$.

While it is generally conceded that small business owner-managers should keep records and use those records, little information about how and if that is being done is available. Linda Pinson notes that record keeping has two functions: (1) To provide the business owner with information indicating trends in the operation-a complete and simple set of records that creates a map of what is happening in the business, (2) To provide income tax information that is easily retrievable and verifiable ${ }^{[16]}$. Longenecker, et al. ${ }^{[13]}$ indicate that a good accounting system should "provide an accurate, thorough picture of operating results, permit quick comparison of current data with prior years' operating results, offer financial statements for use by management, bankers and prospective creditors, facilitate prompt filing of reports and tax returns to regulatory and tax-collecting government agencies and reveal employee fraud, theft, waste and record-keeping errors".

As far as gathering, analysis and preparation of financial data, the trend seen today is small business owners/managers using an in-house record keeping system with an external accountant to complete the needed financial statements. In a study in 1995, Hotch discusses the shift of small business owners to internalizing many of the accounting procedures that they used to hire external professionals to perform in order to save money and increase efficiency, even though "Few people who run small businesses have formal training in accounting",[10]. A 1996 study 
produced the same findings and stated "American Express Small Business Climate Index indicates that small business owners recognize their lack of basic financial and business planning, ${ }^{,[6]}$. The study goes on to say that the primary reason behind the lack of understanding of financial information is that "Small business owners tend to be cash oriented and often have difficulty understanding accrual accounting".

Holmes and Nicholls point out that rarely do small business owners or managers have access to the necessary information to conduct many business activities efficiently. They attribute this to four external environmental factors: Business size, the amount of time under current management, the industrial sector and the business owner's or manager's education level ${ }^{[9]}$. According to the authors, as business size grows, the level of accounting information gathered and prepared grows. This indicates an area of weakness for businesses with few employees. Gobeli and Seville agree with the lack of information by stating "The alarming rate of small business failures each year can ultimately be traced to ineffective management, but one root cause is a lack of good management informationespecially financial information. Larson and Clute present a similar perspective as they describe the 'failure syndrome' that is fueled, at least in part, by a critical, unmet need for usable accounting information" ${ }^{,[8]}$. Finally, McMahon and Holmes concluded in a study in 1991, "Overall, available evidence suggests that the state of knowledge about financial management and the exercise of financial controls and techniques, remains inadequate in small businesses" $^{\text {"[14] }}$.

Accounting software for the small business: Small business owners, though not accountants, need a good record keeping system that allows them to maintain control of the finances of their company so that they are aware of the financial impact of their management activities and have the information to utilize in making decisions that lead to better outcomes. "The most important use is to aid managers in making decisions about the company. Records and reports are primary tools of management. A good manager, like a good worker, keeps the tools of the trade sharp, clean and well organized" [3].

Because the combined list of uses for information from the record-keeping process is overwhelming, it leaves many business owners feeling that recordkeeping and financial data analysis is an impossible task. However, it can become manageable if an accounting software package is used. Day-to-day bookkeeping can be handled by the owner. The end of the year tax accounting and possibly payroll might be turned over to an external accountant.

The accounting process is based on a single premise, every transaction involves money that is "earned, spent, infused into, or taken out of the business" $"[16]$. The records that hold this information must be complete and accurate because they have to be read and interpreted to be of use. An accounting software package gives a better picture of the business's condition while allowing the owner/user to provide financial data to the accountant, tax preparer and bank ${ }^{[5]}$.

Even though computer-based accounting systems have been around since the 70's and are readily available in the market, many small businesses do not seem to be using them. In an AMI-Partners report, Cashing in on the US Small Business Accounting Market, states "A surprising number or existing small businesses have yet to deploy accounting software"[4]. In one recent article, the author stated "Tomorrow's successful small business owners will be far more reliant on technology than their current counterparts" ${ }^{\text {"[11] }}$. The AMI-Partners report went on to state that more than one quarter of firms in the 1-4 employee range still use basic checkbook accounting and manual processes, which they stress is a market worth reviewing for accounting software manufacturers ${ }^{[4]}$. For those that do use computerized accounting tools, they use them simply to replace traditional manual systems and do not use the information available for decision making purposes.

The accounting software market offers a variety of packages. Many are general accounting applications. Others are designed for specific industries. The top choices generally combine those two things and offer modules that will help accomplish certain tasks. Features offered by various packages include: interface, icons, time-billing, use of wizards to help set up the company, pre-built templates for various occupations. Software memorizes repeat transactions and memorizes the forms used. This feature saves time for the user as well as providing consistency in the recordkeeping process. The predominant downside to computerized software is due to the competition between various producers of accounting software. Updated versions appear regularly so that it becomes cost-prohibitive for a small business to maintain technological currency.

There are many accounting software offerings for small businesses. Some of these are QuickBooks, Peachtree, Microsoft Office Small Business Accounting (SBA) and MYOB. Each package has its own advantages and disadvantages and a small business should choose the one that best fits their needs. 
Purpose of study: In the 21st century, small business men and women have access to accounting education, accounting assistance and accounting systems that should allow them to keep good records, with or without the assistance of professional accountants. Based on the fact that most experts think that record-keeping is important, that accounting data can be used to manage better and that there has been little recent research in the area, this project was undertaken. This study presents the results of a national survey of retail clothing and shoe store owners about their record-keeping methods and what use is made of those records. This study is an extension of earlier work by expanding the data set to determine if the preliminary findings held true ${ }^{[7]}$.

\section{MATERIALS AND METHODS}

A questionnaire was designed consistent with the purposes of the study, pre-tested on a small group and revised. The questionnaire asked for demographic information, the person handling the basic bookkeeping for the firm, the qualifications of that person, how the books were kept (manual or computer-based system), whether the firm had or was considering computerbased accounting software, the name of the software, factors used in selecting or considering the software, what the respondents liked/disliked about their software, how frequently the firm produced a set of financial statements and the use made of those statements.

The questionnaires were mailed to a sequential probability sample of 500 retail clothing and shoe store owner-managers selected from Version 2005.1 of Business-info USA ${ }^{\mathrm{TM}}$ in the summer 2005. The sample was restricted to a national sample of the owners of nonpublic retail clothing and shoe stores with less than 20 employees. A questionnaire with cover letter, instructions and return envelope were provided for each respondent. Forty four were returned as undeliverable. Thirty-nine completed questionnaires were returned with the first mailing. A follow up mailing to non respondents was sent four weeks after the initial mailing. Sixty five responses were received from the second mailing. There were 104 useable questionnaires for this analysis from both mailings. This represents a 23\% return. Chi Square was used to test significant differences.

\section{RESULTS}

The findings are presented beginning with business characteristics and personal characteristics. The remainder of the report presents how books are kept, who keeps books, services provided by CPAs, factors used in selecting a bookkeeping system, most and least liked features of systems by computer based respondents and finally frequency of financial statement preparation and uses made of financial statements.

The firms were almost evenly divided between rural, 39.6 and $35.3 \%$ and urban 0.4 and $64.7 \%$ manual and computer based respectively. Manual recordkeeping was significantly higher than computer recordkeeping in firms with sales under $\$ 500,000$ ( $74.1 \%$ Vs $48.1 \%$ ), but in companies with sales greater than $\$ 500,000$, computerized recordkeeping was twice that of manual recordkeeping (51.9\% Vs 26\%). With regard to full time and part time employees, the majority of businesses sampled fell in the 1-5 category for both types of employees, with little difference between those businesses who used computerized and manual recordkeeping.

Computer based firm owners tended to be better educated than those who kept books manually $(67.3 \%$ Vs $52.7 \%$ ) with an undergraduate degree or higher. Females tended toward computer based as did those with fewer years of business experience and less time in business. Evidently those who entered business more recently were more computer-oriented. Younger and marital status, however, did not seem to matter. There were no statistically significant differences between the groups related to personal characteristics.

The numbers of respondents who kept books manually and with a computer based system were about equal. Among the manual systems used, most indicated a more formal manual system (55.4\%), followed by a checkbook based system (23.2\%), a simple pencil and paper system (10.7\%) and a shoebox system (10.7\%).

As shown in Table 1, most of the small business owners kept their own books, $64.3 \%$ manual vs. $51.9 \%$ computer based. More computer based systems were kept by full time (15.4\%) or part time (15.4\%) employees. Manual systems were more often kept by the owner or an external accountant (14.3\%). There was a statistically significant difference between the two groups related to who kept their books.

As shown in Table 2, CPAs were significantly more likely to perform audits $(33.3 \%$ Vs $18.9 \%$ ) for computer based small business owners. General accounting services were significantly more used by manual based small business owners (60.4\%) compared to computer based owners (37.0\%). Write up service were more commonly used by manual owners $(50.9 \%)$ than for computer owners (40.4\%). Manual system owners tended to use CPAs more for taxes (96.2\%) than computer system owners (89.4\%). Payroll was about equal, but considering that computer based owners tended to have more employees, this could represent a different. 
Am. J. of Economics and Business Administration 1 (1) 27-33, 2009

Table 1: Who does accounting in the company?

\begin{tabular}{lccc}
\hline & Manual & Computer & Chi-square \\
\hline No one & 0.0 & 1.9 & \\
Full-time employee & 0.0 & 15.4 & \\
Part-time employee & 5.4 & 15.4 & \\
Self & 64.3 & 51.9 & \\
Spouse & 8.9 & 9.6 & \\
Outsource to company & 7.1 & 0.0 & \\
External accountant & 14.3 & 5.8 & \\
$\mathrm{~N}$ & 56.0 & 52.0 & 0.005 \\
\hline
\end{tabular}

Table 2: CPA performs for company

\begin{tabular}{|c|c|c|c|c|c|}
\hline & Manual & $\mathrm{N}$ & Computer & $\mathrm{N}$ & Chi-square \\
\hline Auditing & 18.9 & 53 & 33.3 & 48 & 0.097 \\
\hline Tax & 96.2 & 53 & 89.4 & 47 & 0.179 \\
\hline $\begin{array}{l}\text { General accounting } \\
\text { services }\end{array}$ & 60.4 & 53 & 37.0 & 45 & 0.020 \\
\hline Payroll & 22.6 & 53 & 23.9 & 45 & 0.881 \\
\hline $\begin{array}{l}\text { Financial statements } \\
\text { Write-up }\end{array}$ & 50.9 & 53 & 40.4 & 47 & 0.292 \\
\hline
\end{tabular}

Table 3: Why not use a computer based system-manual

\begin{tabular}{lcc}
\hline & Frequency & $(\%)$ \\
\hline Expensive & 5.0 & 10.0 \\
Accountant handles externally & 10.0 & 20.0 \\
Too complicated & 9.0 & 18.0 \\
Don't meet needs & 7.0 & 14.0 \\
No one knows how & 9.0 & 18.0 \\
Other reasons: & & \\
Don't have computer & 1.0 & 2.0 \\
Don't like change & 1.0 & 2.0 \\
Don't need it & 1.0 & 2.0 \\
Don't need one & 1.0 & 2.0 \\
Don't use computer & 1.0 & 2.0 \\
Employee's computer & 1.0 & 2.0 \\
Illiterate & 1.0 & 2.0 \\
Established business & 1.0 & 2.0 \\
Haven't taken time & 1.0 & 2.0 \\
The old one works & 1.0 & 2.0 \\
\hline Total & 50.0 & 100.0 \\
\hline
\end{tabular}

Manual bookkeeping owners were asked why they did not use a computer based system. Table 3 shows their responses. Twenty percent indicated that the function is handled externally by an accountant, 18\% indicated that it was too complicated and that no one in their firm knew how, $14 \%$ felt computer based system did not meet their needs and $10 \%$ felt it was too expensive. Several others gave various reasons.

A similar question was asked of computer based owners. The results are shown in Table 4. The features that were touted as the most appreciated included ease of use $(33.3 \%)$ and suitable for their business $(31.9 \%)$, with cost and uncomplicated software (10.1\%) and accountant preference $(5.8 \%)$ and other various features accounting for the rest of the responses. The features that the respondents liked least were that the software was too complicated $(40.0 \%)$ that it doesn't handle all their needs (16.7\%) and it doesn't fit business and upkeep costs (13.3\%).
Table 4: Most and least liked feature-computer-based

\begin{tabular}{|c|c|c|c|c|c|}
\hline Most liked & Frequency & $(\%)$ & Least liked & Frequency & $(\%)$ \\
\hline Cost & 7.0 & 10.1 & Too complicated & 12.0 & 40.0 \\
\hline Ease of use & 23.0 & 33.3 & Doesn't fit business & 4.0 & 13.3 \\
\hline $\begin{array}{l}\text { Suitable for } \\
\text { business }\end{array}$ & 22.0 & 31.9 & $\begin{array}{l}\text { Doesn't handle } \\
\text { all needs }\end{array}$ & 5.0 & 16.7 \\
\hline Uncomplicated & 7.0 & 10.1 & Upkeep costs too high & 4.0 & 13.3 \\
\hline Accountant likes & 4.0 & 5.8 & Other & & \\
\hline Other & & & Discontinued software & 1.0 & \\
\hline $\begin{array}{l}\text { Compatible with } \\
\text { POS system }\end{array}$ & 1.0 & 1.4 & Generally satisfied & 1.0 & 3.3 \\
\hline $\begin{array}{l}\text { Customer } \\
\text { management }\end{array}$ & 1.0 & 1.4 & $\begin{array}{l}\text { No payroll } \\
\text { function }\end{array}$ & 1.0 & 3.3 \\
\hline $\begin{array}{l}\text { Don't have, } \\
\text { don't want }\end{array}$ & 1.0 & 1.4 & $\begin{array}{l}\text { Not enough } \\
\text { information }\end{array}$ & 1.0 & 3.3 \\
\hline Easy to use & 1.0 & 1.4 & Time to build database & 1.0 & 3.3 \\
\hline Nothin & 1.0 & 1.4 & & & \\
\hline Prints checks & 1.0 & 1.4 & & & \\
\hline Total & 69.0 & 99.6 & Total & 30.0 & 99.8 \\
\hline
\end{tabular}

Table 5: What systems have you considered or are you considering

\begin{tabular}{lccccc}
\hline & Manual & $\mathrm{N}$ & Computer & $\mathrm{N}$ & Chi-square \\
\hline Quick books & 61.5 & 26 & 75.0 & 48 & 0.173 \\
Peachtree & 0.0 & 26 & 6.4 & 47 & 0.261 \\
MYOB & 0.0 & 26 & 6.4 & 47 & 0.261 \\
Industry specific & 3.8 & 26 & 2.1 & 47 & 0.589 \\
Excel & 23.1 & 26 & 10.6 & 47 & 0.140 \\
\hline
\end{tabular}

Table 6: Selection factors

\begin{tabular}{lrlccl}
\hline & Manual & $\mathrm{N}$ & Computer & $\mathrm{N}$ & Chi-square \\
\hline Other business person & 23.3 & 30 & 28.6 & 42 & 0.109 \\
CPA/accountant & 29.0 & 31 & 33.3 & 42 & 0.119 \\
Employee & 3.2 & 31 & 4.8 & 42 & 0.117 \\
Reasonable cost & 35.5 & 31 & 19.0 & 42 & 0.022 \\
Personal research & 6.5 & & 19.0 & & 0.046 \\
\hline
\end{tabular}

When asked what systems they had or were considering, the majority of both groups indicated that they were considering Quick Books (Table 5).

A few respondents computer based owners were considering Peachtree and MYOB. A small number of both groups were considering an industry specific system and several manual owners $(23.1 \%)$ and computer based owners (10.6\%) were considering Excel. There were no statistically significant differences between the groups. Eighty eight percent of the computer based owners were satisfied with the system they had.

As shown in Table 6, in selecting a computer based system, $23.3 \%$ of the manual systems owners and $28.6 \%$ of computer based owners would use another business person. CPAs would influence $29.0 \%$ of manual owners and $33.3 \%$ of computer based owners. Reasonable cost was significantly more important to manual owners $(35.5 \%)$ than to computer based owners (19.9\%). Personal research was significantly more important to computer based owners $(19.0 \%)$ than to manual owners (6.5\%). Employees were not particularly important to either group. 
Am. J. of Economics and Business Administration 1 (1) 27-33, 2009

Table 7: Frequency of financial statements

\begin{tabular}{lcll}
\hline & Manual & Computer & Chi-square \\
\hline Never & 9.4 & 1.9 & \\
Monthly & 28.3 & 42.3 & \\
Semi-annually & 7.5 & 13.5 & \\
Annually & 37.7 & 17.3 & \\
As needed & 17.0 & 25.0 & \\
$\mathrm{~N}$ & 53.0 & 52.0 & 0.046 \\
\hline
\end{tabular}

Table 8: Uses of financial statements

\begin{tabular}{|c|c|c|c|c|c|}
\hline & Manual & $\mathrm{N}$ & Computer & $\mathrm{N}$ & Chi-square \\
\hline Pay taxes & 76.0 & 56 & 72.5 & 51 & 0.433 \\
\hline $\begin{array}{l}\text { Reports to } \\
\text { collaborators }\end{array}$ & 42.0 & 50 & 51.0 & 51 & 0.240 \\
\hline Decision making & 34.0 & 50 & 58.8 & 51 & 0.010 \\
\hline Assess performance & 68.0 & 50 & 84.3 & 51 & 0.045 \\
\hline Planning & 34.0 & 50 & 58.8 & 51 & 0.010 \\
\hline
\end{tabular}

Of particular interest in this study is the frequency of financial statement preparation and how those statements are used by business owners. Table 7 clearly shows that significantly more frequent statements are prepared by computer based owners. This indicates that these owners can generate statements regularly or as they are needed. But Table 8 adds to these findings. About equal numbers of both groups used statements to pay taxes and to report to collaborators.

Most authorities agree that financial statement use should include those two, but more importantly they should be used for management. Clearly significantly more computer based owners used their financial statements for performance assessment, 84.3\%, compared to $68.0 \%$ manual owners: Decision making, $58.8 \%$, compared to $34.9 \%$ of manual owners and planning, $58.8 \%$, compared to $34.0 \%$ of manual owners.

\section{DISCUSSION}

The purpose of this study was to gather information regarding small business's approach to capturing, managing and analyzing financial data, in order to better understand issues that are hindering small businesses from realizing the full potential of well organized and utilized financial data. Through the gathering of information for this study, one interesting discovery was made. Approximately half of the respondents, mostly with low to moderate annual sales volume, continue to use manual accounting systems. These systems, while much slower and error-prone in comparison to the computerized counterpart, require substantially more time for reporting and analysis of financial data. Computerized systems have so many reporting and analysis tools incorporated in the software, as well as communication application interaction abilities for information sharing and security.
The percentage of small businesses eschewing the use of computerized tools to aid in financial data management and analysis is considerable. This study demonstrates that there is a lack of timely information necessary for decision making by businesses using manual recordkeeping since financial statements are generated much less frequently. Another finding of this study is that the financial information available is underutilized in most of the applications regardless of the recordkeeping approach. This could be a serious concern to small businesses given the environment in which businesses compete today relies heavily on timely information and on successful information usage for sustaining a strong business presence.

Another finding is that manual system users hire external accountants for more general accounting services than do computerized system users, costing the company additional time and money. Computerized systems provide the ease of use and functionality allowing many of these services to be performed internally.

When asked why the manual system users didn't convert to a computerized system, among the top five reasons were cost, lack of accounting knowledge, limited functionality and the absence of user friendly interfaces. While cases that require special functionality might arise, research shows that most small businesses main use of financial data is relatively simplistic in nature. Tools are built into these software programs than handle the majority of the needs of small business users. These packages are also relatively inexpensive and user friendly. The underlying barrier to adoption might be in the lack of training on the system more so than the reasons given by the respondents.

Finally, when considering adoption of a computerized system, small business owners primarily look at cost and CPA recommendations. This provides practitioners an ideal opportunity to help steer small business owners towards computerized systems. Practitioners understand the potential of using computerized systems and can encourage small business owners through training encouragement and cost-benefit analyses.

\section{CONCLUSION}

Because very little research has been published on recordkeeping practices of small businesses, this research was conducted primarily to get a better understanding of these practices. It should be stressed that the companies surveyed were all in the retail clothing industry, which is a limitation of this study. The AMI-partners report stated that over one-fourth of 
small businesses falling in the 1-4 employee range still use manual recordkeeping ${ }^{[4]}$ and although the percentage of manual recordkeeping use is higher in this study, the AMI-Partners report findings are supported. The percentage of very small businesses in the retail clothing industry that use manual systems is higher, so it could be inferred that the dependence on manual recordkeeping, to some degree, might be industry specific.

Analyzing the data collected (1) on reasons why small businesses are continuing to use manual recordkeeping and (2) on opinions of the computerized recordkeeping software by the companies surveyed indicates that encouraging small businesses to implement and efficiently utilize a computerized recordkeeping system will take more training on the software products, possibly from the software vendors. The employees using the systems, with more training, would be better able to utilize the features present, as well as feel an increased level of comfort and familiarity with the software.

Businesses, small or large, need accurate and timely information for decision making purposes, but this is just the initial step in good decision making. They also need to know how to analyze the data. Taking advantage of the features in computerized recordkeeping is a major step towards improved utilization of the financial information generated in a business and this shift towards computerized support of decision making needs to be encouraged in small businesses.

\section{REFERENCES}

1. Breen, J. and S. Nick, 2002. Use of computerized record keeping in small business. Small Business Research Program, CPA Australia, pp: 1-41.

2. Broida, M. and D. Flora, 1990. The status of computerized accounting software in small American businesses. J. Small Bus. Strategy, 1: 47-50.

3. Carland, J., J. and J. Carland, 1998. Small Business Management: Tools for Success. 2nd Edn., Dame Publishing, Houston, TX., ISBN: 978-0-53492183-5, pp: 56.

4. BNET., 2006. Cashing in on the US small business accounting market: Intuit and Microsoft go head to head.

http://www.marketresearch.com/product/display.as $\mathrm{p}$ ?productid $=1267665 \& \mathrm{~g}=1$

5. Clyman, J., M. McLaughlin, M. Steinhart and S. Gambhir, 2004. Manage your money and employees. PC. Mag., 23: 21-21.

http://www.pcmag.com/article2/0,2817,1723410,00.asp
6. Coates, J.D. and C.R. Borgia, 1996. An opportunity for developing a small business accounting practice. Ohio CPA J., 55: 33-35.

7. Davis, D. and Dunn, P., 2005. You ought to keep good records and use them in management decisions. Proceedings of the Association for Small Business and Entrepreneurship Albuquerque, Nov. 2005, SBANC Newsletter, pp: 1-1. http://www.sbaer.uca.edu/newsletter/2005/110805.htm

8. Gobeli, D.H. and M.A. Seville, 1989. The small business-CPA interface. J. Small Bus. Mgt., 27: 8-16. http://www.questia.com/googleScholar.qst;jsession id=J7PQf8KNYTkTGqcJWz7HbRnLhnzGt4DdJn BtCJCCdSyTZPpyZV3H!155795636 ! 1935866942 ?docId=5000118863

9. Holmes, S. and D. Nicholls, 1989. Modeling the accounting information requirements of small businesses. Account. Bus. Res., 19: 145-150.

10. Hotch, R., 1995. Accounting programs you can more than count on. Nation's Bus., 83: 45. http://findarticles.com/p/articles/mi_m1154/is_n6_ v83/ai_16928877/?tag=content;col1

11. Informer, S.B., 2007. Intuit study finds today's technology hype is tomorrow's small business reality.

http://www.sbinformer.com/news/news/070626Int uit.html

12. Klein, K., 2002. Balancing the books-by the book, Business Week Online. http://www.businessweek.com/smallbiz/content/fe b2002/sb2002021_8853.htm?c=bwfrontierfeb05\&n $=\operatorname{link} 2 \& \mathrm{t}=$ email

13. Longenecker, J., C. Moore, J. Petty and L. Palich, 2006. Small Business Management: An Entrepreneurial Emphasis. 13th Edn., Thomson/South-Western, Mason, OH., ISBN: 0324-31400-0, pp: 506.

14. McMahon, R. and S. Holmes, 1991. Small business financial management practices in north America: A literature review. J. Small Bus. Manage., 29: 27. http://www.questia.com/googleScholar.qst;jsession id=J7VJGnLR2Jp5vB3zG5pJcJJYSN2FTh6yJJFX H2xJp81MLg2FpLYc!$1668351997 ! 1935866942$ ?docId $=5000128453$

15. Moutray, C., 2006. The small business economy: A report to the president. The Office of Advocacy, United States Government Printing Office, Washington. http://www.asiaing.com/the-smallbusiness-economy-a-report-to-the-president-2006.html

16. Pinson, L., 2004. Keeping the Books. 6th Edn., Dearborn Trade Publishing, Chicago, IL., ISBN: 978-0793179299, pp: 1-13. 